A deeper cause of our inferiority, it is suggested, is to be found in defects in our use of the resources already available to industry, and this means a failure of industrial leadership. It is fertility in resource and imaginative enterprise that lie at the roots of material progress. The backward countries of the world are in that position not so much because they lack capital as because they lack industrial leaders. In a country like Great Britain, which cannot now lay claim to any superiority in natural resources over many others, and which is being overtaken by numerous competitors in the oldestablished industries, it is the capacity to carve out new channels of enterprise upon which material progress will depend. The most disquieting feature of the inter-war situation was not that our old industries, in which we were once supreme, declined, but that we did not achieve a foremost position in the new industries that appeared during that time.

The chief contribution to material progress in the future is likely to be made, as it was made in the past, by the industrial leader who uses resources for new productive purposes, and whose massive innovations force the ordinary run of business men out of their routine and so raise the level of efficiency throughout an economy. A society which impedes this kind of activity on the part of the innovators cannot hope for great improvements in its material standards. In recent decades Great Britain has lagged behind other nations in industrial leadership. Our position in established industries has been undermined by developments that took place abroad rather than at home, and, in spite of our scientific achievements, we have not shown the capacity of our fathers, or of the industrialists of some other countries, in ereating new industries. Since our progress in material well-being in the decades ahead is likely to be substantial only if we show exceptional competence as industrial pioneers, this is a cause for grave concern.

It may be that the day of the private entrepreneur, in his role of innovator, is over in Great Britain, and we have to ask whether his function can be performed by some other agency, for example, by the State. In some of the more primitive countries, governments have certainly performed this function with success. But, in those countries, the task has been that of introducing techniques and forms of organisation already worked out elsewhere. Whether governments can be equally successful in developing entirely novel kinds of industry within advanced societies has yet to be shown. Success depends largely upon the selection of the right men for responsibility; and those who in the past have done most for the world in this field have had to work their own way to the light, often in the face of opposition or scepticism on the part of their well-established contemporaries. New industries, for example, have not normally sprung from large, established concerns, but have usually been built up from small beginnings. The government cannot ersily select the right men when they are still unknown and untried for heavy responsibilities, and yet it is from such men that great industrial innovations have usually come.

In the end, whether it is left to the government or to private entrepreneurs, successful innovation has, as its first condition, the existence of a society which welcomes it and which is sufficiently cohesive to withstand the disruption of old ways of life that innovation causes. Whether any particular society possesses the morale which makes it possible to preserve social stability in the face of far-reaching technical changes, just as whether it possesses the energy and will which drive forward a people in the pursuit of material progress, are questions that cannot be considered primarily in the context of economic calculation.

\section{A CHAPTER IN BRIDGE ENGINEERING A CENTURY AGO}

DROF. A. ROBERTSON begins his prosidential address to Section G (Engineering) with the reminder that a hundred years ago, in March 1850, the Brittania Tubular Bridge was opened. In the previous year the report of the commissioners appointed to inquire into the application of iron to railway structures was published. Both are notable instances of the collaboration of engineer, constructor and mathematician which has been so fruitful in engineering. The Bridge was an impressive advance on previous work, not only in size but also in the material of which it was constructed and the manner in which it was erected. In order to complete the Chester and Holyhead railway, the Menai Straits had to be crossed. By making use of the Brittania Rock, the longest span could be kept down to about 470 feet. Robert Stephenson's original proposal of a cast-iron arch (which would have been twice the span of any existing arch) was rejected, and an Admiralty commission demanded a clear passage throughout the whole span of a hundred feet above high water.

Stephenson conceived the idea of a tube (through which the train would pass) which might need to be supported by chains during erection and possibly retained as a permanency. Such a bridge would have to be in wrought iron, although the longest wrought iron bridge at that time was only about sixty feet. He decided on a series of experiments which he placed in the hands of William Fairbairn; who later called in Eaton Hodgkinson. Tubes of 12-24 in. in diameter and 25-31 ft. long were made by rolling sheet to a thickness of $0 \cdot 037-0 \cdot 135$ in. and then riveting. They were tested in bending by a central load. The tests brought into prominence the phenomenon of wrinkling, that is, thelportion under compression failed by crumpling up into folds. Further tests were done on elliptical, square and rectangular tubes. It was decided to build a model one-sixth full scale, 75-ft. span, having a cellular top (compression side) and a single plate for the bottom. The model was tested under a central load. In the first test it fractured under $\mathbf{3 5 . 5}$ tons. Alterations were made, and in the final test the load was 86 tons, corresponding to a stress of $14 \cdot 8$ tons per square inch on the compression side and $18 \cdot 6$ on the tension side.

The final design for the bridge consisted of a series of cells for both top and bottom booms, separated by side plates which were stiffened with vertical angle-iron and gusset plates. The cellular construction was necessary because plates could not be obtained thicker than $\frac{3}{4}$ in. The tubes were constructed on stages built on the shore, so placed that pontoons could later be brought underneath the tube. The first tube (412 ft. long, and actually that for the Conway River) was proof-tested with a load of 300 tons over the middle $300 \mathrm{ft}$. In order to devise the best way of navigating the pontoons on which 
the tube would be carried from the shore to the site, a model of the Straits was constructed and the position of the necessary winches, etc., was settled. On reaching the site, the pontoons were released and the tube rested on the masonry of the base. The tube was raised to its correct height by means of long chains depending from hydraulic presses fixed in the towers. The several spans of the Brittania Bridge form a continuous girder, and this advantage was used when the tubes were finally joined together.

The cellular construction devised for the bridge was adopted by Brunel in $\mathbf{1 8 5 4}$ for his ship the Great Eastern, which in displacement was five times that of any vessel then being built and fifty years ahead of her time. Structurally she was a great success.

Before the Britannia Bridge, most railway bridges were built of stone, brick, timber or cast-iron. For many of the short ones, cast iron was used as a beam, and for some (up to about a hundred feet long) several castings were bolted together. Sometimes these were designed with a trussing of wrought-iron tension bars. The failure of a bridge of this type led to the appointment in 1847 of a Royal Commission. The important clause in the terms of reference was : "They shall endeavour to ascertain such principles and form such rules as may enable the engineer and mechanic, in their respective spheres, to apply the metal with confidence and shall illustrate by theory and experiment the action which takes place under varying circumstances in iron railway bridges which have been constructed". This clause excited considerable opposition among the engineers of the day who feared the possible formulation of rules to be observed.

The Commission concerned itself almost entirely with cast iron, and deliberately refrained from expressing any opinion on wrought iron. It instituted a series of valuable experiments on such varied topics as : the repeated application of load with and without impact, the effect of a slowly moving weight applied many times $(96,000)$, and the effect of a weight moving with velocity over a beam. The whole report represents an extraordinarily fine achievement for less than two years work, since it contains the first experiments on many subjects of vital importance to engineers. Fxcept for Fairbairn's experiments on wrought-iron built-up girders in 1860-61, nothing of importance was published on the resistance of metals to repeated loadings until Wöhler's classical work in 1870.

\section{INFLUENCE OF FOOD PLANTS ON SOCIAL STRUCTURE}

$\mathrm{D}^{\mathrm{R}}$ REDCLIFFE N. SALAMAN'S presidential address to Section $H$ (Anthropology and Archæology) is concerned with the social repercussions in Britain of one of the latest food plants, namely, the potato ; for man's first need is food, and its character and acquisition largely determine his way of life.

The potato reached Spain about 1570 and the British Isles during the last decade of the sixteenth century.' For the next hundred years in the south and midlands of England it remained a luxury raised in the kitchen gardens of the great houses. In the north its advance was more rapid and deployed over a broader social base. This difference was in the main due to the absence of the open field and the greater economic freedom of the workers in the north, created by competition between agricultural and mining interests. From about 1700 onwards the potato was eaten because it was liked, not because it was necessary.

In the south and midlands the cultivation of the potato was much slower and followed a different course. In general, the working classes ignored it. About 1725, market gardens sprang up outside London and the middle classes became interested in the new food. In 1778 the London retail price was $\frac{1}{2} d$. a lb., or one-eighth the price of meat. In 1939 it was one-eighteenth, which partly explains why the tuber was not adopted earlier by the lower-paid town workers.

After the turn of the eighteenth century, farmer and labourer began to take an interest in the potato, first feeding it to their pigs and horses, and only when it was obvious that it did not poison them was it included in their dietary. On the evidence of Arthur Young, so late as 1784 , the potato had made little progress in the homes of the rural workers. Prior to 1750, workers had been satisfied with a mixed wheat and barley or rye and barley loaf, while the well-todo enjoyed a white wheaten one. A change gradually took place; the brown loaf was discarded and with it the social implication following the use of two standards in respect to the staple of life.

War and the disastrous harvests of 1794 and 1795 caused the price of the quartern loaf to rise in twelve months from $7 d$. to $1 s$. $1 d$., and later to reach $1 s$. $5 d$. Wages showed no appreciable rise for some time and never fully covered the rise in the cost of living. In 1770 the average worker's daily wage could purchase two loaves, in 1780 one and a half, in 1800 four-fifths of a loaf, and in 1810 a whole one; not until 1850 could it aequire the same amount of bread as it had in 1770. To meet the crisis workers were invited to return to the mixed loaf or accept a potato and wheaten loaf; both were refused. After great privation, a compromise was found by the adoption of the potato as a major article of diet. The economic effect was deplorable. The cost of living was lowered and wages stabilized at the lowest possible standard. Other factors undoubtedly helped to make the lives of the workers so incredibly sordid during the first half of the nineteenth century, but none was more insidious than the potato.

The influence of the potato in England is the merest reflexion of that it wielded in Ireland. Its arrival coincided with the later stages of a long and devastating war. To a starving peasantry, literally without home or property, came this heaven-sent food. As easy to grow as to hide from the military, satisfying and palatable, its future was never in doubt. Probably in little less than a century it was the native Irishman's main, and sometimes his sole, source of food. Such a dominance is almost unique in man's long history. By fostering unlimited procreation, the potato decontrolled the size of the family, dictated the routine of work, the tenure and use of the land, and the amenities of the home. A mono. phagous peasantry with the lowest standard of living in Europe afforded unlimited scope for exploitation, socially, politically and industrially. The opportunity was not neglected in eighteenth-century Britain.

In the nineteenth century, when a far better understanding existed between the two countries, the destruction by blight of the potato crops in 1845 and 1846 led to a disaster without parallel until recent days. Nevertheless, so firmly established was the habit that, in relation to the size of the population, 